\title{
The Role of Apa-I Vitamin D Receptor Gene Polymorphism in Type 2 Diabetes Mellitus
}

\author{
Mutiara Indah Sari ${ }^{1 *}$, Rusdiana Rusdiana ${ }^{1}$, Milahayati Daulay ${ }^{2}$ \\ ${ }^{1}$ Department of Biochemistry, Faculty of Medicine, Universitas Sumatera Utara, Medan, Indonesia; ${ }^{2}$ Department of Physiology, \\ Faculty of Medicine, Universitas Sumatera Utara, Medan, Indonesia
}

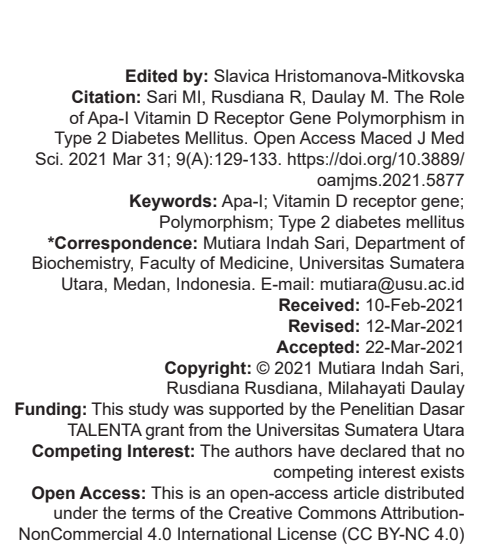

Abstract

BACKGROUND: Type 2 diabetes mellitus (T2DM) is a chronic metabolic syndrome caused by insulin secretion abnormalities, insulin action, or both. Gene polymorphism is a risk factor of T2DM.

AIM: This study aims to see the role of Apa-I Vitamin D receptor gene polymorphism on T2DM.

METHODS: This study was an analytic observational with a case-control approach, consisting of 70 T2DM patients and 70 healthy subjects as a control. Genotyping of the Apa-I Vitamin D receptor gene polymorphism was performed using the polymerase chain reactions-restriction fragment length polymorphisms method. The role of the Apa-I Vitamin D receptor gene polymorphism and the risk of T2DM were analyzed using the Chi-square test.

RESULTS: The results showed that there was a significant association between codominant (TT genotype); dominant; recessive models of the Apa-I Vitamin D receptor gene polymorphism with the risk of T2DM ( $p<0.05$; odds ratio $[\mathrm{OR}]=0.204,95 \%$ confidence interval $[\mathrm{Cl}]=0.063-0.662 ; \mathrm{OR}=0.337,95 \% \mathrm{Cl}=0.113-1.004 ; \mathrm{OR}=0.367$ $95 \% \mathrm{Cl}=0.180-0.747$, respectively), but not in codominant (GT genotype) and over-dominant models $(p>0.05)$.

CONCLUSION: This study shows a role of the codominant (TT genotype); dominant; recessive models of the Apa-I Vitamin D receptor gene polymorphism on T2DM, but not in codominant (GT genotype) and over-dominant models.

\section{Introduction}

Diabetes mellitus (DM) is a chronic metabolic syndrome with signs of hyperglycemia. Hyperglycemia occurs due to abnormalities in insulin secretion, insulin action, or both. About $90 \%$ of all DM patients are type 2 DM (T2DM). Based on the International Diabetes Federation in 2019, there were 463 million T2DM patients in the world, and the number of T2DM patients is estimated to increase to 700 million in 2045. In 2019, Indonesia ranked as the second highest number of T2DM patients in the West Pacific region after China, with an estimated of 10.7 million patients [1]. Base on the data of the Indonesian Ministry in 2013, in North Sumatra found $1.7 \%$ cases of T2DM and the number of T2DM patients is estimated to increase to $1.9 \%$ of cases in 2018 [2].

T2DM is one of the metabolic diseases that are underdiagnosed. About 30\% of T2DM patients are often unaware of their condition, and by the time, the diagnosis is made, $25 \%$ have already developed microvascular complications. The mean delay from onset to diagnosis is estimated to be about 7 years. It is necessary to know the risk factors for this disease for earlier diagnosis and even more efficient prevention [3], [4].

The risk factors of T2DM are genetic, lifestyle, and environment [5]. Nowadays, the researchers suggest that single-nucleotide polymorphisms (SNPs) of the Vitamin $D$ receptor gene are among the risk factors in genetic groups that play a role in T2DM. The human Vitamin D receptor gene is located on chromosome 12q12-q14. SNPs are genetic variant in Vitamin D receptors that can affect the activity of Vitamin $D$ receptors and their ligands, namely, 1,25(OH)D. Furthermore, the binding of Vitamin $D$ receptors and their ligands will affect the metabolic process in cells [6], [7].

The previous studies on the T2DM population in Jeddah, Saudi Arabia, showed the genotype and allele of the Apa-I Vitamin D receptor gene polymorphism as a risk factor for developing T2DM [8], but on the T2DM population in Turkey and Mexico showed the different results [9], [10]. Based on differences in the previous studies in various populations, this present study aims to analyze the role of the Apa-I Vitamin D receptor gene polymorphism in T2DM patients in the Universitas Sumatera Utara Hospital.

\section{Materials and Methods}

\section{Ethics}

This research was conducted in June-October 2020 , after obtaining approval from the ethics committee 
of the Universitas Sumatera Utara (Ethics Number: 160/ KEP/USU/2020), the director of Universitas Sumatera Utara Hospital. The research subjects have explained the objectives, benefits, procedures, and risks of this research following the ethical principles of the Second Declaration of Helsinki. All research subjects signed informed consent after the explanatory of this study. All information and data collected from research subjects are guaranteed confidentiality and are only used for scientific purposes.

\section{Study subjects}

This study was an analytic observational with a case-control approach consisting of 70 T2DM patients and 70 healthy subjects as a control. T2DM subjects were recruited at the Universitas Sumatera Utara Hospital, Medan, North Sumatra Province. The diagnosis of T2DM was based on the Indonesian Endocrinology Society, following criteria of PERKENI, Indonesia. Healthy subjects as controls were randomly recruited among staff at the Faculty of Medicine, Universitas Sumatera Utara, based on the results of their fasting glucose and glycated hemoglobin (HbA1c) test [11].

T2DM and the healthy groups had one or all of the conditions, such as T2DM with complications, T1DM, chronic infections, and malignancy, were also excluded from the study. Healthy subjects with a family history of DM were also excluded from the study.

\section{Fasting glucose, HbA1c, and genotype analysis}

Measurement of fasting glucose levels and $\mathrm{HbA1c}$ for T2DM and healthy subjects was carried out at the Universitas Sumatera Utara Hospital using a 6000 analyzer with hexokinase immunoturbidimetry method. The genomic DNA was extracted from the subjects peripheral venous blood, using the Promega Wizard Isolation Kit (US). Genomic DNA measured using Nanodrop spectrophotometric with the absorbance at $260 \mathrm{~nm}$ and $280 \mathrm{~nm}$ wavelengths to determine DNA concentrations and purity.

Genotyping of the Apa-I Vitamin D receptor gene polymorphism was carried out using the polymerase chain reactions-restriction fragment length polymorphisms (PCR-RFLP) method. Amplification was performed using primers.

\section{F- 5'CAACCAAGACTACAAGTACCGCG TCAGTGA-3'; R- 5'CACTTCGAGCACAAGGGGCGTTAGC- 3'(Macrogen, Singapore).}

PCR was carried out with annealing at $61^{\circ} \mathrm{C}$ for $2 \mathrm{~min}$, with 35 cycles. PCR products were identified on $2000 \mathrm{bp}$. The PCR product was digested by Apa-I restriction enzyme at $37^{\circ} \mathrm{C}$ for $4 \mathrm{~h}$ (Thermo Scientific TM). The result of Apa-I enzyme digestion was visualized with $4 \%$ agarose. The result was $\mathrm{GG}=2000$ bp, GT $=2000,1700$, and $300 \mathrm{bp}$, and TT = 1700 and 300 bp [12].

\section{Data analysis}

Data analysis was performed using SPSS version 21 software. Hardy-Weinberg equilibrium (HWE) of Apa-I Vitamin D receptor gene was tested using the Chi-square goodness-of-fit test with $p>0.05$. The Chi-square statistical test or Fisher's exact test was performed to determine the odds ratio (OR) of the relationship between the Apa-I Vitamin D receptor gene polymorphism and risk of T2DM, with a confidence interval $(\mathrm{Cl})$ of $95 \%$ and $p<0.05$.

\section{Results}

The study included 70 T2DM patients and 70 healthy subjects. The gender distributions were 75 (53.6\%) male and 65 (46.4\%) female. The mean age was $49.20 \pm 14.95$ years.

Table 1 shows that fasting blood glucose and $\mathrm{HbA} 1 \mathrm{c}$ levels in the T2DM patients were 216.02 \pm 100.89 and $9.03 \pm 2.18$, respectively, and in healthy subjects were $91.19 \pm 9.36$ and $5.42 \pm 0.32$, respectively.

Table 1: Fasting glucose and HbA1c levels of the studied groups

\begin{tabular}{lcl}
\hline Variables & T2DM $(n=70)$ & Control $(n=70)$ \\
\hline Fasting glucose, $\mathrm{mg} / \mathrm{dl}$ & $216.02 \pm 100.89$ & $91.19 \pm 9.36$ \\
HbA1c, \% & $9.03 \pm 2.18$ & $5.42 \pm 0.32$ \\
\hline Data in meantstandard deviation. T2DM: Type 2 diabetes mellitus, HbA1c: Glycated hemoglobin.
\end{tabular}

PCR and RFLP products of Apa-I Vitamin D receptor gene polymorphism are shown in Figures 1 and 2.

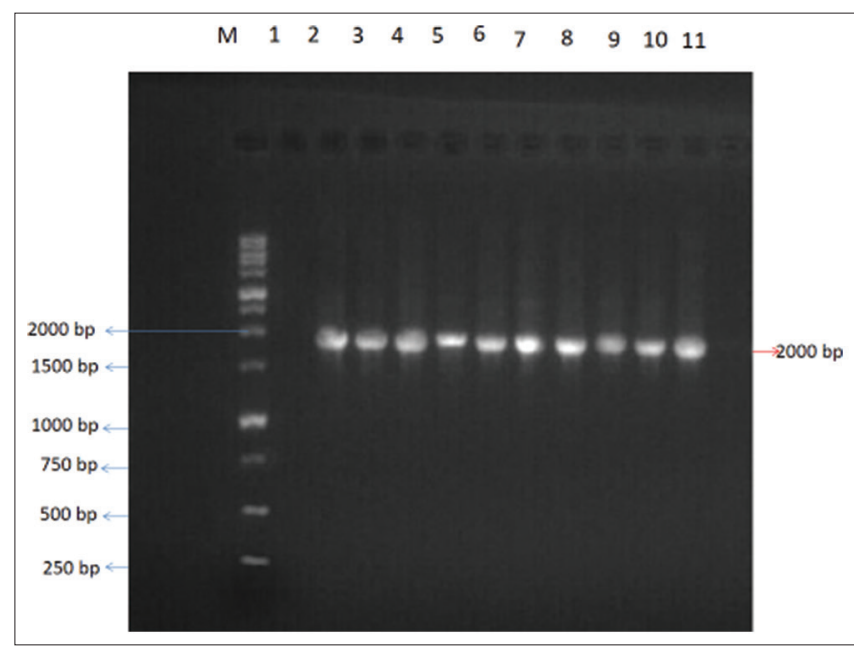

Figure 1: Polymerase chain reactions product of Apa-I Vitamin D receptor gene in $2 \%$ agarose gel electrophoresis. Lane $M$ is a $1 \mathrm{kbp}$ ladder, lane 1 is a negative control, lanes 2-11 represent of Apa-I Vitamin D receptor gene (2000 bp) 


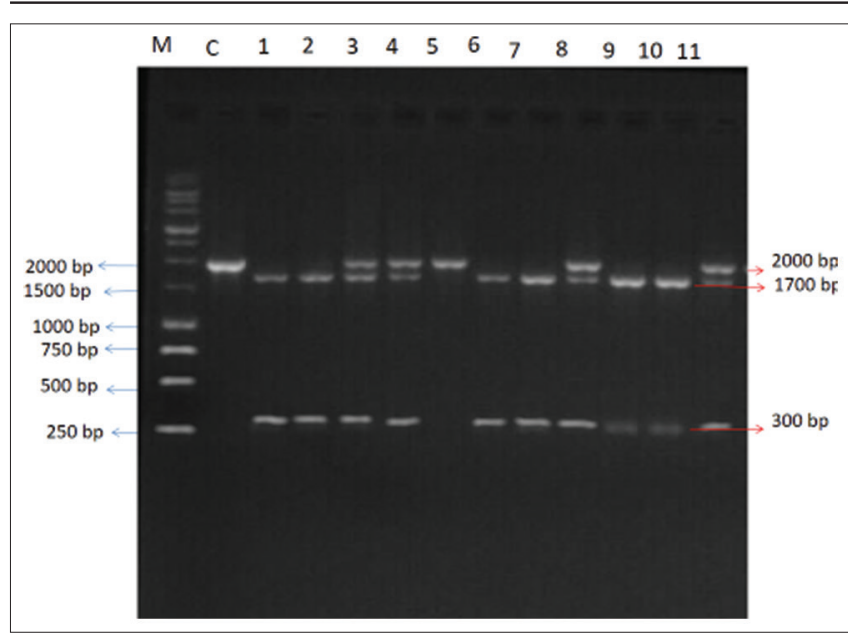

Figure 2: Polymerase chain reactions (PCR)-restriction fragment length polymorphisms product of Apa-I Vitamin $D$ receptor gene polymorphism in $4 \%$ agarose gel electrophoresis. Lane $M$ is a $1 \mathrm{kbp}$ ladder, lane $C$ represents $P C R$ product as control, lanes 1, 2, 6, 7, 9, and 10 represent homozygote mutant TT (1700 bp and $300 \mathrm{bp}$ ), lanes 3, 4, 8, and 11 represent heterozygote GT (2000 bp, $1700 \mathrm{bp}$, and $300 \mathrm{bp})$, and lane 5 represents homozygote wild-type GG (2000 bp)

Table 2 shows a statistically significant difference between TT, TG, GG genotypes, and A, T alleles of Apa-I Vitamin $D$ receptor gene polymorphism in the T2DM patients and healthy subjects $(p<0.05)$. The Chi-square goodness-of-fit test showed that there was a balance of HWE in Apa-I Vitamin D receptor gene polymorphism for each T2DM and control group $(p>0.05)$.

The association between all genetic models of the Apa-I Vitamin D receptor gene polymorphism and the risk of T2DM is shown in Table 3 . There is a significant association between codominant (GG vs. TT); dominant (GG vs. GT + TT); and recessive (GG + GT vs. TT) models of the Apa-I Vitamin $D$ receptor gene polymorphism with the risk of T2DM $(p<0.05)$. In this study showed that codominant, dominant and recessive models of Apa-I reduced risk of T2DM $(\mathrm{OR}=0.204,95 \% \mathrm{Cl}=0.063$ $0.662 ; \mathrm{OR}=0.337,95 \% \mathrm{Cl}=0.131-1.004 ; \mathrm{OR}=0.367$, $95 \% \mathrm{Cl}=0.180-0.747$, respectively). In contrast, there was no association between codominant (GG vs. GT) and over-dominant GG + TT versus GT of Vitamin D receptor gene polymorphisms and T2DM ( $p>0.05)$.

\section{Discussion}

In this study, an analysis of the distribution of genotypes and alleles of the Apa-I Vitamin D receptor
Table 3: Association of Apa-I Vitamin D receptor gene polymorphism in studied groups according to genetic models

\begin{tabular}{|c|c|c|c|c|}
\hline Polymorphism & Genetic models & OR & $95 \% \mathrm{Cl}$ & $\mathrm{p}$-value \\
\hline \multirow[t]{9}{*}{ Apa-I (G>T) } & Codominant & & & \\
\hline & GG versus GT & 0.484 & $0.156-1.504$ & 0.204 \\
\hline & GG versus TT & 0.204 & $0.063-0.662$ & 0.006 \\
\hline & Dominant & & & \\
\hline & GG versus $\mathrm{GT}+\mathrm{TT}$ & 0.337 & $0.113-1.004$ & 0.043 \\
\hline & Recessive & & & \\
\hline & GG+GT versus TT & 0.367 & $0.180-0.747$ & 0.005 \\
\hline & Over dominant & & & \\
\hline & $\mathrm{GG}+\mathrm{TT}$ versus $\mathrm{GT}$ & 1.583 & $0.812-3.084$ & 0.176 \\
\hline
\end{tabular}

OR: Odds ratio.

gene polymorphism in T2DM patients and healthy subjects was carried out. There was a statistically significant difference between TT, TG, GG genotypes, and $A$, T alleles of Apa-I Vitamin $D$ receptor gene in the T2DM patients and healthy subjects $(p<0.05)$.

Polymorphism is a difference in DNAsequences between one individual to another, from one group to another, or from one population to another. SNPs are the most common form of polymorphism. SNIPs are a substitution of one nucleotide base in DNA sequences between purines $(A, G)$ and pyrimidines $(C, T)$ or between purines and pyrimidines. Genotypes and alleles of the Apa-I Vitamin D receptor gene polymorphism vary widely between different populations. Geographical differences, ethnic diversity, and lifestyle in a population are thought to cause variant in the genotypes and alleles of the Apa-I Vitamin D receptor gene polymorphism in each population [7], [13].

Nowadays, the researchers that theApa-IVitamin $\mathrm{D}$ receptor gene polymorphism is associated as a risk factor for several diseases including T2DM [6], [14], [15]. This study found a significant association between codominant (TT genotype); dominant; recessive models of the Apa-I Vitamin D receptor gene polymorphism with the risk of T2DM but not in codominant (GT genotype) and over-dominant models.

The previous study on the T2DM population in Saudi found that the genotype and allele of the Apa-I Vitamin $D$ receptor gene were a risk factor of T2DM [6], but a study in the Moroccans population showed no association between all genetic models of Apa-I polymorphism and T2DM [16]. The other previous study showed that the genotypes and alleles of Apa-I Vitamin $D$ receptor gene polymorphism are not associated with risk of T2DM in the population of Pakistan [17]. An earlier literature review study showed that of 15 studies, none of which showed a significant association between the Apa-I Vitamin $D$ receptor gene polymorphism and the risk of T2DM ( $n=171-4563$ ), as well as the two other meta-analyzes that analyzed the risk of T2DM in 3871 individuals [18], [19], [20].

Table 2: Genotype and allele frequency of Apa-I Vitamin D receptor gene polymorphism and HWE test in the studied groups

\begin{tabular}{llllll}
\hline Polymorphism & Genotype/allele & T2DM patients $\mathrm{n}(\%)$ & Control $\mathrm{n}(\%)$ & $\mathrm{p}$-value & HWE in T2DM patients $\chi^{2}(\mathrm{p})$ \\
\hline Apa-I (G>T) & TT & $18(25.7)$ & $34(48.6)$ & 0.009 & $1.01(0.32)$ \\
& TG & $39(55.7)$ & $31(44.3)$ & & \\
& GG & $13(18.6)$ & $99(70)$ & & \\
& T & $75(53.6)$ & $41(29.3)$ & 0.003 & \\
& G & $65(46.4)$ & & & \\
\hline
\end{tabular}


Susceptibility to suffer from T2DM is related with changes in the ability of Vitamin $D$ receptors to bind to $1,25(\mathrm{OH}) \mathrm{D}$. Polymorphism of the Apa-I Vitamin $D$ receptor alters the activity and affinity of this receptor binding to $1,25(\mathrm{OH}) \mathrm{D}$. Changes in activity and affinity of Vitamin $\mathrm{D}$ receptors will be changed circulating of $1,25(\mathrm{OH}) \mathrm{D}$ which, in turn, affects sensitivity and resistance of insulin [10], [21]. The previous studies demonstrated the $A A(G G)$ genotype of the Apa-I Vitamin D receptor gene polymorphism were significantly associated with lower insulin resistance $(p=0.035)$, in response to Vitamin D supplementation [22].

This research needs to be continued by involving a larger sample size and measuring the levels of Vitamin $D$ and insulin to understand how the mechanism of association between the Apa-I Vitamin D receptor gene polymorphism and the risk of T2DM. We expected that the results of this study became feedback for further research.

\section{Conclusion}

This study shows that there was an association between codominant (TT genotype); dominant; recessive models of the Apa-I Vitamin $D$ receptor gene polymorphism with the risk of T2DM but not in codominant (GT genotype) and over-dominant models. Codominant (TT genotype); dominant; recessive models of the Apa-I Vitamin $D$ receptor gene polymorphism play a role in reducing the risk of $\mathrm{T} 2 \mathrm{DM}$ in this population.

\section{Acknowledgments}

Researchers would like to thank the funding of this research by the Universitas Sumatera Utara, under the research grant of Penelitian Dasar TALENTA, Universitas Sumatera Utara, of the Year 2020 (No.4142/UN5.1.R/PPM/2020). The authors gratefully acknowledge all subjects as participation in this study.

\section{References}

1. International Diabetic Federation. IDF Diabetic Atlas. Brussels, Belgium: International Diabetic Federation; 2019. Available from: https://www.idf.org/aboutdiabetes/what-isdiabetes.html. [Last accessed on 2020 Oct 20].

2. Badan Penelitian dan Pengembangan Kesehatan Kementrian Kesehatan Republik Indonesia. Riset Kesehatan Dasar. Jakarta: Kemenkes RI; 2018. p. 87. Available from: https://www. litbang.kemkes.go.id/laporan-riset-kesehatan-dasar-riskesdas.
[Last accessed on 2020 Oct 20]. https://doi.org/10.6066/ jtip.2013.24.2.121

3. Buell C, Kermah D, Davidson MB. Utility of A1C for diabetes screening in the 19992004 NHANES population. Diabetes Care. 2007;30(9):2233-5. https://doi.org/10.2337/dc07-0585 PMid: 17563338

4. Saudek CD, Herman WH, Sacks DB, Bergenstal RM, Edelman D, Davidson MB. A new look at screening and diagnosing diabetes mellitus. J Clin Endocrinol Metab. 2008;93(7):2447-53. https:// doi.org/10.1210/jc.2007-2174

PMid: 18460560

5. Hu FB. Globalization of diabetes: The role of diet, lifestyle, and genes. Diabetes Care. 2011;34(6):1249-57. https://doi. org/10.2337/dc11-0442

PMid:21617109

6. Uitterlinden AG, Fang Y, Van Meurs JB, Pols HA, Van Leeuwen JP. Genetics and biology of vitamin $D$ receptor polymorphisms. Gene. 2004;338(2):143-56. https://doi.org/10.1016/j.gene.2004.05.014 PMid: 15315818

7. Valdivielso JM, Fernandez E. Vitamin D receptor polymorphisms and diseases. Clin Chim Acta. 2006;371(1-2):1-12. PMid:16563362

8. Iyer A. Association of Apa I polymorphism of vitamin d receptor gene with type 2 diabetes mellitus in Saudi population. J Exp Biol Agric Sci. 2017;5:271-6

9. Dilmec F, Uzer E, Akkafa F, Kose E, van Kuilenburg $A B$. Detection of VDR gene Apal and Taql polymorphisms in patients with Type 2 diabetes mellitus using PCR-RFLP method in a Turkish population. J Diabetes Complications. 2010;24(3):18691. https://doi.org/10.1016/j.jdiacomp.2008.12.002 PMid:19186074

10. Rivera-Leon EA, Palmeros-Sanchez B, Llamas-Covarrubias IM Fernandez S, Armendariz-Borunda J, Gonzalez-Hita M, et al. Vitamin-D receptor gene polymorphisms (Taql and Apal) and circulating osteocalcin in Type 2 diabetic patients and healthy subjects. Endokrynol Pol. 2015;66(4):329-33. https://doi. org/10.5603/ep.2015.0042

PMid:26323470

11. Perkumpulan Endokrinologi Indonesia (Perkeni). Konsensus Pengelolaan dan Pencegahan Diabetes Melitus Tipe 2 di Indonesia 2015. Pengurus Besar Perkumpulan Endokrinologi Indonesia (PB Perkeni). (The Indonesian Association of Endocrinologists.Consensus for the Management and Prevention of Type 2 Diabetes Mellitus in Indonesia 2015. Executive Board of the Indonesian Endocrinology Association; 2015. Available from: https://www.pbperkeni. or.id/wp-content/uploads/2019/01/4.-Konsensus-Pengelolaandan-Pencegahan-Diabetes-melitus-tipe-2-di-IndonesiaPERKENI-2015.pdf. [Last accessed on 2020 Sep 20]. https:// doi.org/10.23886/ejki.3.4810.

12. Haddad S. Vitamin-D receptor (VDR) gene polymorphisms (Taq-I \& Apa-I) in Syrian healthy population. Meta Gene. 2014;2:646-50. https://doi.org/10.1016/j.mgene.2014.08.005 PMid:25606448

13. Ismail S, Essawi M. Genetic polymorphism studies in humans. Middle East J Med Genet. 2012;1(2):57-63

14. Mahyar A, Ayazi P, Sarkhosh Afshar A, Naserpour Farivar T, Sahmani M, Oveisi S, et al. Vitamin D receptor gene (Fokl, Taql, Bsml, and Apal) polymorphisms in children with urinary tract infection. Pediatr Res. 2018;84(4):527-32. https://doi. org/10.1038/s41390-018-0092-y PMid:29976973

15. Zhang K, Song L. Association between Vitamin D receptor gene polymorphisms and breast cancer risk: A meta-analysis of 39 studies. PLoS One. 2014;9(4):e96125. https://doi.org/10.1371/ 
journal.pone. 0096125

PMid:24769568

16. Errouagui $\mathrm{A}$, Benrahma $\mathrm{H}$, Charoute $\mathrm{H}$, Ghalim N, Barakat $\mathrm{A}$ Kandil M, Rouba H. Relationship between Vitamin $\mathrm{D}$ receptor (VDR) gene polymorphisms and susceptibility to Type 2 diabetes mellitus in Moroccans population. Int J Innov Appl Stud. 2014;8(2):503.

17. Ashraf Z, Ameen M, Ahmad S, Manzoor H, Gulshair M. Association between Vitamin D Receptor (VDR) Gene Polymorphisms and Type-2 Diabetes Mellitus in Population of Pakistan. J Clin Med Genomics. 2018;6(153):2. https://doi. org/10.4172/2472-128x.1000153

18. Alathari BE, Sapta AA, Kalpana CA, Vimaleswaran KS. Vitamin $D$ pathway-related gene polymorphisms and their association with metabolic diseases: A literature review. J Diabetes Metab Disord. 2020;19:1701-29. https://doi. org/10.1007/s40200-020-00561-w PMid:33553043

19. Li L, Wu B, Liu JY, Yang LB. Vitamin D receptor gene polymorphisms and type 2 diabetes: A meta-analysis. Arch Med
Res. 2013;44(3):235-41.

PMid:23506721

20. Wang Q, Xi B, Reilly KH, Liu M, Fu M. Quantitative assessment of the associations between four polymorphisms (Fokl, Apal, Bsml, Taql) of vitamin $\mathrm{D}$ receptor gene and risk of diabetes mellitus. Mol Biol Rep. 2012;39(10):9405-14. https://doi. org/10.1007/s11033-012-1805-7

PMid:22814767

21. Zaki M, Kamal S, Basha WA, Youness E, Ezzat W, El-Bassyouni $\mathrm{H}$, et al. Association of Vitamin $\mathrm{D}$ receptor gene polymorphism (VDR) with vitamin $\mathrm{D}$ deficiency, metabolic and inflammatory markers in Egyptian obese women. Genes Dis. 2017;4(3):176-82. https://doi.org/10.1016/j.gendis.2017.07.002 PMid:30258921

22. Jain $R$, von Hurst $P R$, Stonehouse $W$, Love DR, Higgins $C M$, Coad J. Association of Vitamin D receptor gene polymorphisms with insulin resistance and response to Vitamin D. Metabolism. 2012;61(3):293-301. https://doi.org/10.1016/j. metabol.2011.06.018

PMid:21871642 